\title{
Bank Liability as Trustee in Banking Insolvency
}

\author{
Franciska Mifanyira Sutikno1, Indah Dwi Miftachul Jannah² \\ 1 Postgraduate Study, Universitas Airlangga Surabaya, Indonesia \\ fransiska.mifanyira.sutikno-2017@fh.unair.ac.id \\ 2 Postgraduate Study, Universitas Airlangga Surabaya, Indonesia \\ indah.dwi.miftachul-2017@fh.unair.ac.id
}

\begin{abstract}
Introduction to The Problem: A trustee agreement is an exclusive agreement in banking gives the bank the right and authority to manage the customer's assets as stated to the agreement The assets of trust assets are the property of the customer, the management of the assets must be separately carried out to implement the Prudential Principle and Pacta Sunt Servanda in banking contract.

Purpose/Objective Study: Research and analyze the legal consequences of the trustee agreement and analyze the bank liability towards the insolvency status to the trustee agreement.
\end{abstract}

Methodology/Approach: This Legal Research used normative positivism with the using of the Statute and Conceptual Approach. The Legal Research Sources divided into primary to the tertiary source.

Findings: The research shows that the Bank is only as the manager of the asset; therefore, every legal conduct shall have approval from the Settlor under the trustee agreement. It means, if the assets are included as insolvency assets, it is a violation of contract as well as law where the dispute settlement shall be taken into account.

Paper Type: This Research is Reseach Article completed by rules and regulations. Keywords: Banking; Legal Protection; Liability; Insolvency; Trustee agreement

\section{Introduction}

The era of globalization creates a society that depends on banking as an intermediary institution (Wafa, 2017; Wiwoho, 2014), but the banking institution also provides and maintains the functions in managing customer assets (trust service). Trustee Service is one of the banking services legalized by the authority which allows the Bank to receives deposits and manages the financial Assets. At first glance, trust service seems similar to Investment Management services as regulated in Law Number 8 of 1995 on Capital Market related to the authority of banks as managers of customer's wealth. The bank is not the same as an Investment manager as long as banks subjected to banking law as legal standing to apply its obligations. Banking Law and Banking Rules should not be separated from the management of trust assets. That is why the investment managers are subject to capital market laws and regulations of financial service authorities, and financial managers personally have different codes ethics and mechanisms and standards for asset management.

Some provisions exist that distinguish Trust Services from other banking services. The prominent provisions could be mentioned, such as trust service is separated from the banking unit, the asset management is limited to financial assets, and there must 


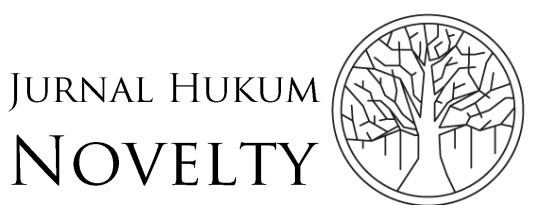

Volume 10, Issue 02, 2019, pp. 111-129

be the prevention of customer assets to be included in bankruptcy assets if the bank declared insolvent. Concerning the threat of insolvency, the Bank, as one of the major actors in the Indonesian economic system, should overcome banking health problems that lead to insolvency. The existence of insolvency risk in general view might be examined through financial report that leads to the understanding of financial distress and the probability of financial failure or economic failure (Budhijana \& Nelmida, 2018; Ramadhani \& Lukviarman, 2009). With the risk of failure, legal issues are emerging, such as position and legal effects between banks and customers in trustee agreements, and the existence of forms of customer legal protection, especially if trust assets are set to be included in bankruptcy assets. If the bank fails and leads to liquidation, the curator or third party will take over the bank.

The trustee agreement gives Bank rights on behalf of the customer to manage the assets for specific terms and conditions. Prabandani (2015) stated that trust service divided into two kinds, such as Private Trust and Public Trust. Private Trust is implemented to the private sector legal relationship such as Bank and Customer in the Trustee Agreement. Meanwhile, the Public Trust is implemented to the extensive business, such as the government, which needs on public projects. The trustee agreement still needs the role and function of the Bank as an intermediary and asset manager. In Indonesia, every conventional and or sharia bank could have the Trustee Agreement after being approved by Indonesia's Financial Service Authority. The bank should at least prepare the administration related document but not limited to: 1 ) Human Resources to operate the trustee agreement, 2) general information of trustee agreement or design of trustee agreement, 3) trustee Agreement terms and conditions for both parties, 4) trustee agreement assets and or obligations managed by Bank, and 5) Other factors that related to the trustee agreement.

The legal issue analyzed in this paper is legal consequences of trustee agreement between Bank and the other party, and the Bank Liability in the case of being Declared as Insolvent along with the Trustee agreement. The limitations of this paper, such as the Bank limited to Conventional Bank and Private (not designed as state-owned banks).

\section{Methodology}

The legal method used in this study is the normative method that used law and regulations as the primary source of legal research. This method enhanced by several other materials such as primary, secondary, and third legal materials.

The legal approaches used in this paper are the statute approach and the conceptual approach towards the implementation of banking services and liability or bank liability for negligence and violation of trustee agreements. It enhanced by an in-depth analysis of standardization and mechanism for selecting and separating customer's assets from bankruptcy assets. The primary legal materials used in this research were laws and regulations, along with theories and legal concepts, while secondary legal 
P-ISSN: $1412-6834$

E-ISSN: 2550-0090

materials include journals and legal books, the third material taken from internet sources, and electronic dictionary.

The data used in the research is the literacy of national legislation as the main rule in this study. Other data used are examples of trustee agreements and or standard clause rules made between banks and customers in a trustee agreement to study and analyze the form of bank liability to customers as long as the trustee agreement runs and what specific factors influence the termination of the agreement the trust. The data used do not use sample or field studies because this legal research is juridical normative legal research. The analysis that has carried out will follow the approaches and methods of legal research, continued by collecting and analyzing the laws and regulations governing the trustee agreement followed by the use of secondary and tertiary legal sources.

\section{Results and Discussion}

\section{Legal Consequences of a Trustee agreement}

A Bank is a Legal Entity and Business Entity which are created not only for maintaining people's needs in providing money or investment through the banking products, but it developed in Indonesia for giving many services. Because banks have existed in the business sectors, it means that banks could make, modified, and also create any banking agreement based on social needs. Kaori Saito, Kazunori, and Kyosuke (2018) stated that since the Bank in every state are connected to the Building Information System, it means the legal activities would be supervised not only by the national law and regulations but also the BIS regulations such as the progress of solving the claims and liabilities by the reports (Siato, Hiyama, \& Shiotani, 2018).

The creation of new services would not be any problem as long as the administrative procedures and operational principles are appropriate to the Bank Establishment Purposes. Banking Agreement should not also be limited as long as the contract substance is based on the contract rules and principle. Since Indonesian Burgerlijk Wetboek acknowledges freedom of contract principle, the Bank and customer could give their consent to agree upon any form of contract that excluded the Burgerlijk Wetboek. There are some principles of contract that also need to be implemented that is after the consent to bind themselves into a contract; there would be legal effects upon the parties. Wafiya (2012) stated that in the banking globalization, the consent is not only implemented in the conventional service which requires the face to face meeting but also the transactions which are using the Internet via Mobile Banking and electronics without reducing the agreement characteristic to the risk prevention. The background of this development services is based on the use of standard contract clauses and also the practical activities and bargaining power of the Bank to the customer (Abubakar \& Handayani, 2017).

Based on Banking Law, Bank has a right to do some activities included operating some operational Banking instruments and services such as Deposits, Savings, Credits, 


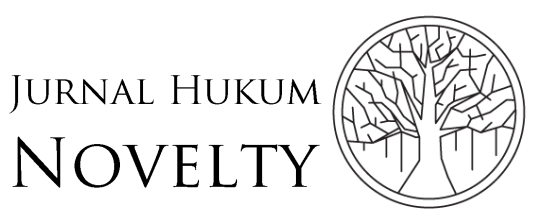

Volume 10, Issue 02, 2019, pp. 111-129

Notes, Bill of Exchange, Banker Acceptances, Commercial Papers, Treasury Bills, Bonds and other services related to the Functions as Intermediary Institution. Sharia Bank also has a similar service even though there are differences related to the sharia principles applied to the operational conduct (Syamlan, 2017). Nevertheless, in this study, the analyzed subject is only conventional banks. Bank, especially conventional banks, has the freedom to manage the operational standards relating to the service preparation and service execution to the society since Bank has legal standing as the corporate or company. This legal standing should be implemented not only in the freedom of making and legalizing the services but also the terms and conditions of the service as long as adjusted to the company law and regulations and also bankingrelated laws and regulations. Still, this freedom is not absolute since Bank also stands as a financial institution under the supervision of Financial Service Authority, which always and thoroughly supervises and examines the administration and or establishment of the service to prevent any legal violations.

Among the used services and banking Instruments by the Customer, there is one unique service that differs from the Bank from another financial institution, which is the trustee agreement. Based on the Indonesian term, there are two legal conducts agreed between Bank and Customer. The first agreement is Bank has given rights to receive the assets by the Customer, and second, the Bank also has given authority to do management activities towards the assets.

Compared with another Financial institution such as Cooperation and Financing Company, Bank has different mechanisms and operational procedures in this service, especially when Bank shall bear and prevent the risk occurred by the management conduct. This Management Conduct in Trustee is not quietly the same as the Investment Manager function in the stock market to manage the Investment instrument since the Trustee Agreement could also be related to the property management excluded the stock market system. Trust is a Banking Service created by Bank and legalized by law and regulations to given rights for a Bank to manage, operate, regulate and/or supervise the flow of funds from the business activities of a Customer. Trust Services was initially held by Trust Companies or Trust Banks abroad. In the Development of the Banking system, Conventional Banks are given rights to do so for the importance of Asset diversifications in the Business sectors. Based on Indonesia Banking Law, Trust is included in Bank Business Activity related to any specific agreement to manage any securities. Trustee agreement is special since it is related to the contract regime, which needs any modifications in terms and clause even though it has already regulated by law. Since Bank is given the right to receive and manage the assets, it should be obvious that Bank is neither the owner nor the beneficial owner.

World Bank made Operational Manual related to the Trustee agreement Procedures Number BP 14.40 in July 2008 as Revised in July 2015. Based on Section Initiation Number 1 of Trustee agreement giving freedom of any legal persons individually or 
P-ISSN: $1412-6834$

E-ISSN: 2550-0090

another defined purposes as long as Bank could manage the administration and trustee agreement enforcement (The World Bank, 2015). Not only reflecting the benefits to the Customer who used the service, but trust service income received by Bank could be used to develop this trust through partnership since the risk of trustee agreement related not only for Customer's assets but also the law implementation rank on Bank. The gaining and enjoying any flow of funds through business activities or provided by a financial institution were rights for every Indonesian citizen. Those rights might be applied concretely by investment and/or saving funds. The increasing number of public funds sources, especially financial instruments but located not in Indonesian jurisdiction, make the state face the obstacles providing welfare of society. Internationally, trust service related to funding management divided into several varieties such as Programmatic Trust Funds and Freestanding Trust Funds, which distinguish and differ the Fund management mechanism based on the legal subject and the purposes of trust (Concessional Finance and Global Patnership, 2009). This Complexity is also implemented by the report and supervision by Indonesia Central Bank to maintain the aspects of the agreement in parts of Trustee Human Resources, Trustee agreement and Settlor Qualification, Trustee Activities, and Liabilities of Bank along with the Bank obligations (Ginting et al., 2013).

Trustee agreement is an agreement considered as the Un-named Agreement or onbenoemde overeemkomsten. This is a common theory since Indonesia Civil Code is only regulated the ordinary and simple agreement related to daily life and not intended to maintain the existence of a specific business contract. All parties that enter into an agreement have the right to make and ratify agreements that are different from each other, especially in the presence of freedom of contract or the Autonomy Partij. Based on Article 1319 Burgerlijk Wetboek, it can be concluded that "all agreements, both named and unnamed, are subject to the provisions of Book III Burgerlijk Wetboek". Furthermore, the freedom to make agreements with names, forms, and desired clauses can refer to Article 1338 Paragraph (1) Burgerlijk Wetboek, stated that "all agreements made legally apply as laws for those who make them." So that in this case, both legal entities and individuals who have legal skills capable of making an agreement outside the provisions of Burgerlik Wetboek as long as appropriate to laws and regulations and public order (Hartana, 2016). The development of the trustee agreement has developed the kind of un-named agreements. Trustee agreements are based on open systems and principles of freedom of contract. Contract Law adheres to an open system to provides the widest possible freedom choice and consent for the community to enter into agreements and enforcement, which would not violate laws, public order, and morality. The Freedom of Contract as factor maker of Trustee agreement is regulated in Article 1338 paragraph 1 Burgerlijk Wetboek which written:

"All agreements made legally apply as laws for those who make them". By emphasizing the words 'all', the article seems to contain a statement to the 


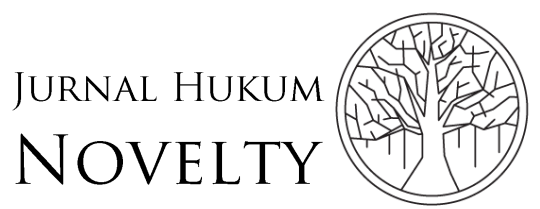

Volume 10, Issue 02, 2019, pp. 111-129

public that we are allowed to make agreements in the form of anything or anything, and the agreement will bind them to make it like a law."

The Concept of Trustee agreement is quite clear on the division of Customer and Bank's rights and obligations towards Trust Assets and how the agreement could give each party mutual benefits. The Ratio Legis or legal considerations regarding the making and ratification of banking services is none other than the interests of economic development in the country. According to this understanding, it can be concluded that the legal politics of making trustee agreements is not merely to meet individual and business needs, but in the broad sense, the existence of trust services also has an impact on the management of existing funds in a state. Article 6 Letter (i) juncto Article 9 of the Banking Law explains that all legal relationships between customers and banks, especially the use of banking services, are based on agreements. The nature of the legal relationship between banks and customers is more accurately said as a trust relationship before entering the trustee agreement.

The principle of trust as a principle must be held firmly in the management of the banking industry since Trustee agreement would be related to the existence of the Customers' asset to manage. The use of the principle of trust as the legal basis for banking agreements between customers and the banking parties is not solely because the customer's assets will be managed by the Bank, but in this case, the banking system is also strengthened and based on the Prudential Principle relating to the banking image in society. With the importance of banking functions in the social life of society, banks can create any guidance and standard form of agreements to facilitate the Prudential Principle. This act is permissible as long as there are mutual consent and agreement, as provided in Article 1320 Burgerlijk Wetboek (Indonesia Civil Code). The Banking should explain and rule the prudential principles as the complex guidance and rules to keep the financial and or assets owned by Bank safe and solvent, Prevent the misconduct and failing potentials, to give the guidance in the event of restructuration and or resolution and also prevent the system-wide risk which could affect to the bank existence (Cranton \& All, 2017). The Basel III Banking System in Indonesia also implemented the Prudential Principle in establishing and also maintaining the existing Bank with strengthening the quality and level of capital and dividing the Core Tier Into 3 level.

Trustee agreements made and agreed upon among customers based to Bank Indonesia Regulation Number 14/17/PBI/2012 established on 23 November 2012 juncto Bank Indonesia's Circular Letter Number 15/10/DPNP juncto Financial Services Authority Regulation Number 25/P0K.03/2016 on July 15, 2016 juncto Regulation Number 27/POJK.03/2015. The agreement affected the legal position of the depositors of funds called "Settlor" (Customer) and recipient bank called "Trustee" (Bank) and also the third parties as beneficiaries (Customer or other parties). The Bank has new authority as a paying agent, investment agent, and financing for and on behalf of the settlor. In other words, the Bank has fulfilled its 
P-ISSN: $1412-6834$

E-ISSN: 2550-0090

obligations as agent and letter of attorney recipient based on the form of rights and obligations and authority as in accordance with Article 1317 Burgerlijk Wetboek. The bank shall not carry out activities or legal actions that exceed the limits of its authority, as stipulated in Article 1338 Burgerlijk Wetboek and the Principle of Pacta Sunt Servanda. Bank Indonesia also pointed some obligations for Bank in establishing it is own trustee service with several documents to show intentions and serious commitment such as Principle Permission and Letter of Confirmation from Indonesia Central Bank (Hukum Online, 2013). The administrative terms and conditions are regulated not only for maintaining the legality of the Trust service but also designated as a filter in the prevention of illegal activities similar to Trust being used by Bank. Administrative conditions should be first tier and first filter for executing and conducting the service before Bank could enter the second tier; Agreement or contract.

Banks are required to be careful because agreement which has made can affect the risk and reputation of the Bank. The risk also related to the management of customer assets in the form of other financial instruments. Banks must ensure that the source and legality of ownership of these assets were not originated from criminal acts, especially the Corruption and Money Laundering Crimes. If the Bank failed to imply the legality of customers' asset leads to the legality of the trustee agreement. Bank would not be charged if it proved to receive the criminal assets from the Customer unless the authorities find the contrary facts leads to the acknowledgment of the Bank itself of the criminal assets being saved and managed by a customer. On the other hand, the Bank has obligations to examine the identity of Customers carefully and also the specifications of every asset. These examinations affected the bank decision, whether it would agree for implying the agreement or refuse the Customer.

Trustee agreement might be concerning in the bank role to manage the asset, but the agreement core is not related to the trustee function. The trustee function will not happen if no customer is willing to give the bank the rights to manage it. The core of Trustee agreement is related to the assets of a customer as the object of the agreement, while the functions of the bank as Trustee are related to the rights and obligations that have concluded by each party. The customers' assets that have indicated as the results and or tools for doing crimes would affect the sustainability of the contract. Based on Article 1320 Burgerlijk Wetboek, an agreement could be terminated by law as null due to the violation of law related to the assets. In this case, the bank could gain several losses so it could plead for loss claim to the Court and or arbitration based on the contract. Still, the assets shall be the customer's assets, and free of criminal background lied in it.

The legal examination by bank to prevent money laundering in trustee agreement also reflected by Indonesia Central Bank Regulation Number 19/10/PBI/2017 which implied Legal Due Diligence divided into 4 (four) variety such as Customer Identification conduct, Identity Verification based on information collected, Doing On- 


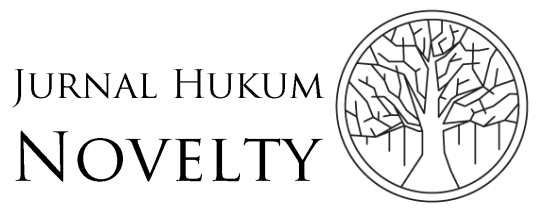

Volume 10, Issue 02, 2019, pp. 111-129

Going Due Diligence and examine the source and or the legal relationship between assets and customers' background. This Regulation also divided the legal standing of assets' holder and Beneficial Owner on the asset. Beneficial Owner usually recognized for it is a position to control and command the asset while the settlor is a party who was actively doing an agreement with the Trustee. Ridwan Arifin and Shafa Amalia (2019) mentioned that Government also intervenes in private sector agreement with guidance, law, and regulations based on Good Corporate Governance and strictly arranges the broad and or rigid characteristic of money laundering. The Money Laundering through Trustee Agreement could be assessed by several factors such as the transaction, or agreement deviated from the pattern of common transactions, the risk of unreported agreement or transactions to the authority and the agreement object should be suspected is the form of any crime (Setiawan, 2017).

Trust assets that have been taken and deposited by the Bank are not owned by the Bank because Bank has no legal standing to own it. Banks are only holders of bezit rights (right to hold but not own) or material rights of Settlors, which are strengthened by trustee agreements as an agent and as a recipient of power. This separation of trust property with banking assets is an implementation of the Principle of "Public Order" in the Agreement. Trustee agreement and Trust Service among the states often vary and adjusted to the law, but in the meaning of the protection and separation of Customer's assets from the Bank, the asset is a must, especially when the asset varies from the property, securities, and another derivatives instrument. There must be a good connection and or good coordination between Bank, Customers, and or linked assets instrument as long as the Bank manages the assets'. Nevertheless, the asset which could be included in the agreement is only Financial assets and not for property assets.

There are no exact regulations explicitly differ the banking asset and customers included as Public Order's factor since this agreement is only bound and implied by contracting parties. But Society knows the importance of separations since the Bank should have engaged many Trustee Agreements. Soedikno Mertokusumo explains that the Public Order is a limitation and regulator of the rights and obligations of each party so that later, it will not harm one after another (Mertokusumo, 2010).

As the recipient of the power of attorney and agent, the Bank only has the right to receive safekeeping and management services, namely service fees. Using the customer assets without legal basis and legal standing is an absolute implication of Legal Obligation of Bank based on Prudential Principle and Violation Contracting Parties related to the guarantee of safety management in the Trustee agreement. In the event of a loss arising from the management of the Trustee agreement by Bank, Bank is obliged to compensate based on several terms and conditions. It is necessary to determine which assets will be a guarantee for the implementation of the Bank's responsibilities. 
P-ISSN: $1412-6834$

E-ISSN: 2550-0090

The Trustee agreement affects third parties. The existence of the Bank's power and authority as managers of customer assets (financial instruments) are related to the financial instrument. Financial Instruments in Indonesia are offered and traded as securities as stipulated in the Capital Market Law and Regulations - Financial Services Authority Regulations. The Bank, as an agent, has the right to invest in the name of the settlor as long as it brings benefits to the agreement. The essence of this authority must also be regulated completely, in detail and clearly as stipulated in Article 7 paragraph (1), paragraph (2) and paragraph (3) of the Financial Services Authority Regulation Number 27 of 2015 directly through Trustees or Investment Managers in accordance with the type activities or instruments used in the Trustee agreement. Investment Manager is those whose business activities manage securities portfolios for customers or manage collective investment portfolios for a group of customers, as referred to in the Law on Capital Markets. When using an Investment Manager rather than Trustee, the investment manager should have a separated agreement of the settlor and Trustee to prevent overlapping of authority and also the incompatibility of the rights and obligations of each party. The other party affected by the existence of this trustee agreement is the party that has an obligation to the settlor and the party entitled to fulfill the obligation on the settlor. For a party that has an obligation to the settlor, it will not affect the performance of the Trustee in implementing the agreement as long as the settlor receives the fulfillment. If the settlor has an obligation to pay the debt to a third party using a financial instrument, it will be handed over to the Trustee as a debtor's agent; the authorization does not affect the repayment of debt or liability due to the absence of the settlor responsibility to the Bank. Even though a bank acts as a paying agent representing a settlor, it does not mean a Novation (Debt Upgrading) or Delegation (Transfer of Debtor Status). However, in this case, the settlor has an obligation to notify the creditor related to Trustee agreement as part of the Good Ethics. Related to the debt repayment or the obligation to use trust assets will not raise a problem, as long as the Bank and the Customer consider the risks regarding the payment deadline, and they communicate with the creditor as the recipient of the repayment.

\section{Bank Liability with the Inclusion of Bankruptcy Assets}

The Contract between Bank and Customer in the Trustee Agreement creates rights and obligations between them. As stipulated in the law and regulations, Bank as a Trustee has to comply with several restrictions upon its functions such as the management and the contract implementation regarding the trustee agreement.

The Restrictions that shall be expressly written in the contract are:

1. Trustee agreement and operational made and executed separately from another banking service. The limitation is an absolute obligation bear to the Bank as the Service Provider. This Separated management of Trustee and Bank is to provide the legal certainty of an exact number of Bank assets that would be divided due to some legal problems such as insolvency. 


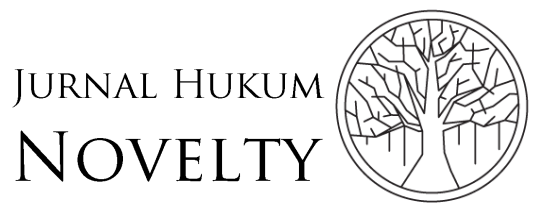

Volume 10, Issue 02, 2019, pp. 111-129

2. The Trustee only manages financial assets. Financial assets could relate to the financing and investment asset, which is used by the customer and settlor along with the agreement. In this agreement, the settlor could set the obligations and rights of the Bank to manage the financial asset independently or cooperate and coordinate with the private auditor or management as long as not make the Bank as the main Trustee get loss or damage.

3. Settlor's financial assets have to be separated from the trustee asset. This separation should be regulated and also stated in the Trustee agreement, along with the proof and clear distinction among the assets.

4. Trustee agreement made in written evidence. The Specific of written Agreement, which is elaborated in the Indonesia Law and Regulations related to the Banking Agreement mainly concerned and made in the Notarial Deed to bind the parties. Fifth, the Trustee has to maintain the secrecy of settlor's identity and or other confidential information related to the trustee Agreement. The Asset management not only needs a professional Bank that is experienced to do management for years but also needs a Bank which understands and implements such an ethic code of a manager. The Bank has given rights to manage and arrange the asset's list document, but Bank is prohibited from opening any confidential information except the information is asked by the authorities.

Specifically, the Trustee has several obligations. Firstly, making and dismissing the settlor account. The account should be integrated into the Bank account as the Trustee since the financial management and financial report is related to the Bank Account Efficiently. Secondly, saving the financial asset's income to the settlor's account. The income gained by the Bank as the Trustee Service is not the same as the income of the Bank. The Agreement of the Bank income should be agreed in the Trustee Agreement and be separated. Lastly, paying settlor's obligation to third parties on behalf of settlor's name.

The management service is not limited to the financial management but also the chances of the Bank to help the settlor to manage the cash flow of the settlor's asset. Some transactions, along with the Trustee Agreement, could not be fixed alone by the Settlor, so the Trustee is asked to help to manage and to fulfill the obligation of the financial obligation. The parties, as the obligation receiver, should be entirely informed along with financial management. Since the asset is still the Settlor's legal ownership, it means the payment and the usage the asset should be under the supervision and approval based on the agreement and Manage and arrange documents related to the financial assets of the settlor.

The trustee is forbidden to conduct some activities. Using Settlor's asset is for private interests. This kind of legal conduct of using the Settlor's asset along with the agreement absolutely violates the law, and the usage considered as the criminal conduct or even breach of conduct depends on how both parties agreed on it. Conducting some activities violate the Trustee agreement. The Conducts shall not 
P-ISSN: $1412-6834$

E-ISSN: 2550-0090

only occur based on the Trustee initiative, but also the Settlor shall not order and or request Trustee to do so, and the Trustee shall not use the Settlor account, which is designed by Foreign Banks.

Before a legal problem occurs, the Bank and the customer can make adjustments through an agreement. Whereas if a legal problem occurs, the party who violates the agreement must be held accountable as a legal obligation. A bank should prepare the mechanism in preventing and dealing with the risk related to the agreement, such as legal and operational risk. An audit is one of the procedures stated in law and regulations to ensure the procedure implementation. Audit in Trustee agreement divided into two varieties, such as Internal Audit and External Audit. Internal Audit is concerned to the administrative requirement of a bank on Core capital, Minimum Capital, Bank Health condition Meanwhile External Audit of a Bank concerned about (BIS, 2014) Difficulties of Internal Audit, Material, and Financial misstatement, Significant Management judgment, Internal Control Efficiency, Reports, and disclosures, also interrelation of Managements by Directors and other workers.

Insolvency in the Banking sector is not a new case in Indonesia since the insolvency cases in the crisis time in 1998. The Government and the customer of Bank Service began to realize that the Banking system that builds and managed by the prudential principle could be violated by the internal parts of the Bank intentionally or without any consent, based on the external factors. The factors and insolvency which occur in the banking system made the Government began to readjust the banking law system supervision in preparing the backup and assistance to every claim by any parties whose might affect the operation (Johanes, 2016). The insolvency soon began to divide by the Government based on the background and factors that lie the legal status. While insolvency could systemically affect the National, Insolvency is more directly since the background of insolvency is when the Bank could not deliver its obligation to pay Creditor of the amount of Credit Payment (Onakoya \& Olotu, 2017). These lead to the request from the Creditor to bind the Bank in the Insolvency status and being managed by third parties named Curator. The curator would manage all of the Bank Asset that listed in the Bank Financial Reports and or other supplementary documents. The Curator not only filed the assets of Bank as the payment based on the creditor positions but also manage and choose the assets on the name of Bank to be guaranteed and used in Insolvency Asset known as Boedel Pailit. The Insolvency Asset should be meet some characteristics such as The Asset is Bank's, as proved by Legal Ownership Document, The Asset is part of the income received by Bank and Asset is considered by the Curator to give any benefit in the increment.

The process of insolvency is completed and implemented in the Insolvency Act. The process would be coordinated held by the bank and curator, but the legal issue occurred in the event of insolvency is when the Bank without any permission and or approval from the Settlor include the Settlor's asset as the part of Insolvency asset to save the bank status for being declared as Insolvent. This condition might happen 


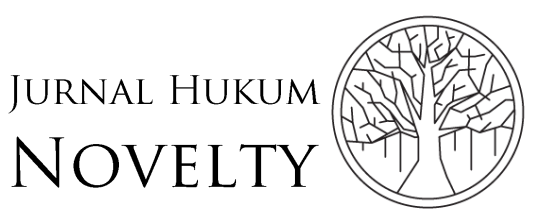

Volume 10, Issue 02, 2019, pp. 111-129

since the settlor has given bank full access to manage and control the settlor's asset on behalf of Settlor, and the bank is not implementing the Prudential Code and also the contract. Munir Fuady stated that in the event of Insolvency, Bank as Company represented by Directors has to implement "Independence Principle" to fulfill the loss of the Creditor using the Bank Assets except for the conditions such as: First, Directors proved to do mal-conduct or director violate the law and regulations and or rules in the Company Deed. Second, Directors proved to do Breach of Contract and or onrechtmatige daad or Criminal Conduct. Third, Directors proved to violate the Business Judgement Rule and Fiduciary Duty Principle. Fourth, Directors proved to violate ultra vires principle, and Directors proved to violate the Piercing the Corporate Veil Doctrine (Fuady, 2017). Piercing Corporate Veil is the main principle in the problem solving to prove the default or negligence done by Directors in preventing and managing the contract implementation. Even if the Directors object the suspicion, the Bank shall asses and prove it comprehend through General Meeting of Shareholder. If there no reason to bear the burden of liability to the Bank, the General Meeting of Shareholder should express it to release and discharge the burden of proof on a specific legal issue. Still, the insolvency problem should be solved by the Directors and the Bank for another loss and damaged to the third parties (Lubis, 2018).

Meanwhile, based in Company Act year 2007, Bank also has liability as represented by Directors as the managing organ in the Banking Company. This liability is not only to appoint the bank obligations but also to implement the Insolvency act in law and Regulations. Based on Insolvency Act Number 2004, the principle in processing to insolvency is the Proportional Principle, Sustainable Principle of Business, Just Principle, and Integration of the Insolvency Legal Entity. The assessment of the violations and the obligations which still not implemented should be acknowledged integrated among the Directors, Commissioners, Curators, and Governments, especially if the Bank is included as the systemic Bank and or government bank. The Directors should be liable to the loss and damage in the case of insolvency and additional liabilities along with the insolvency based on the collegial principle, especially if other parties could prove the violations by the fault, violation based on intent or criminal liability along with civil liability.

The violations of any terms and or conditions by Bank stated in contract lead to the responsibility and or liability should be bear by Bank. The usage of Settlor's asset fulfills the Bank Obligation with any consideration is prohibited since the Trustee Agreement made and implemented separately by the Trustee Business Activity. The Curator should examine and confirm the legality of the asset ownership, or else Curator would bear liability as to the Bank representative. Rachmadi Usman stated that Curator is a representative of Insolvency Legal Entity upon the insolvency test and the party responsible for managing and dividing the liability to the payments on the parties in maintaining the legal certainty and justice (Usman, 2016). This role needed to enforce and encourage the Curator to manage the process objectively and 
P-ISSN: $1412-6834$

E-ISSN: 2550-0090

honest based on the fact to divide the assets, which must remain to the specific parties based on the kind of contract or agreement. Maria Gabrielle J mentioned that the curator role would not stop until the progress and process of insolvency pointed to the concrete decision by the parties and the authorities; to proceed and or to do another legal actions, this means that the Curator has to ensure that the decision is inkracht in two ways based on Pacta Sunt Sevanda and or there is no legal action after the decision made (Siregar, 2016).

The Curator, which found the legal violation of a Bank to include the Trustee Asset into the Insolvency asset, shall inform the fact to the related parties such as Settlors, Creditors, Trustee, and also the Financial Authority Service to proceed the legal liability based on the Trustee Legal Conduct. Sriti Hesti mentioned that Curator has to do so since Curator is considered by the law independently and has no legal interest to the Bank and or the Settlor (Hesti, 2016). This independency should be implemented by several principles of knowledge, skill, and ethic to the morality of the profession. This responsibility is implemented as a form of liability. Examining which kind of liability is the Bank's liability, there must be a brief theory to support liability implementation. According to J.H. Nieuwenhuis, liability should be proven among the illegal act (onrehmatige daad), cause (oorzaak), and guilty (schuld) (Nieuwenhuis, n.d.). Liability begins with a non-compliance with the agreement and results in a loss from one of the parties. There are three liabilities in general, namely strict liability, liability due to errors, and negligence liability (Krismen, 2014).

Indonesia Law has given the opportunity to react to the contract violation to not include the Settlor Asset to any account or any Bank's Business Activity based on Contractual Side. Article 1243 Burgerlijk Wetboek divide the factors of Breach of Contract into several conducts such as First, Debtor (Bank) has not implemented any obligations (zero obligations). Second, Debtor has not implemented the obligation based on the contract. Third, Debtor has not implemented the obligations at the right time, and Fourth, Debtor has implemented the obligations, but the implementation along with the breach of rules and regulation in the contract. For instance, the liability of the Bank would be determinate in the contract or agreement. If Settlor found any violation of a contract, Settlor could proceed with the violation through the contract mechanism. The violation of contract could be related to the management and or usage of the Settlor's financial assets along with the contract implementation. Since the core of the contract or agreement is to manage financial assets, this leads to the obligation for a bank to prevent it mixed to another asset, especially when it comes to the insolvency in Bank operational. There is no possibility of a Mixture between Bank assets and customer's assets since the beginning of agreement based on contract terms and conditions and as the implementation of Prudential Principles. The Possibility of inclement of Settlor's assets would happen if Trustee and or Curator.

However, If the entry of customer assets as bankruptcy assets are carried out by the competent party in the regulation of bankrupt assets, then the liability is the 


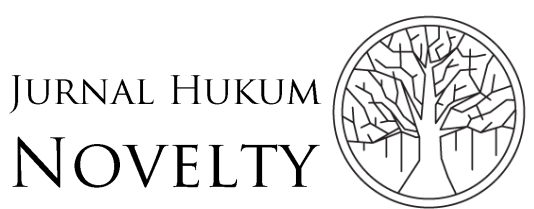

Volume 10, Issue 02, 2019, pp. 111-129

responsibility of the Bank with compensation in accordance with the number of bankrupt assets entered. Whereas in the event of bankruptcy, assets are carried out by parties who do not have authority in the agreement. The liability that should be charged is not on behalf of the Bank but based on individual liability, namely the bank employee. This also relates to the Respondeat Superior principle that occurs when a superior or banking official instructs employees with a lower legal position and position to include the assets as bankrupt assets so that this responsibility belongs to the boss who instructs the employee. The Respondeat Superior requires several factors to prove that the conduct is done in the hierarchy system, and it is impossible for the Bank member as perpetrator or violator helper to refuse the order since it would affect his/her sustainable position in the Bank. Referring to Article 1365 of Burgerlijk Wetboek it is liable on the basis of acts against the law, as well as mistakes made by the maker. Liability without error, a matter which in some laws is regulated as it should (the liability as long as the person concerned has sufficient financial leverage and the loss cannot be sued for a replacement rather than the third party who is obliged to supervise) (Hatrik, 2012). In the case of including customer assets as bankruptcy assets in a Trustee agreement that has been made between Trustees and Settlors, both parties are obliged to implement the agreement as well as possible and avoid legal actions that can harm one party. As explained in the introduction, the problems that occurred in implementing banking services are nothing but related to the condition of banking as a service provider. The more Banking got prepared for liquidity risk, the more banks could distinguish and resolve the insolvency problems.

Whereas in the event that the bankruptcy of assets is carried out by parties who do not have authority in the agreement, the liability that should be charged is not on behalf of the Bank but based on individual liability, namely the bank employee. This also relates to the Respondeat Superior principle that occurs when a superior or banking official instructs employees with a lower legal position and position to include the assets as bankrupt assets, so that this responsibility belongs to the boss or leader who instructed the employee especially if the employee does not know the consequences law from the implementation of said order thus any legitimate authority that is sourced from the law or agreement can cause responsibility for the executor, in this case, the trustee. Referring to Article 1365 Burgerlijk Wetboek, the party is liable on the basis of acts against the law, as well as mistakes made by the maker.

In the event of insolvency, the capability of banks to carry out these activities will be temporarily taken over by Bank Indonesia, the Financial Services Authority, and the Curator instead. Because the element of capability is a subjective element in an agreement, the trustee agreement in the framework of banking insolvency can be deemed by both parties because the Bank will not be able to carry out activities anymore; the authority represents the customer. The Representation shall not violate the with some proven principles of lousy intention, negligence, and recht vaardigdingsground (Yudh, 2017). The responsibility of the Bank in the trustee 
P-ISSN: $1412-6834$

E-ISSN: 2550-0090

agreement is to carry out asset management activities based on agreements and instructions from Settlor and not be held responsible for losses in management, especially in investments made in the Capital Market or Stock Exchanges (PBI No 14/17/PBI/2012 Article 7 paragraph (4). Ratio Legis, for the release of the Bank's responsibility for investment losses, is due to the position of the Bank only as a proxy that communicates and offers investment to the Settlor as the real asset owner. Based on the agreement, provisions can be made regarding the mechanism for the use of customer assets for investment as well as arrangements for granting approval for such actions at a certain time. Other than that in Bank Indonesia Regulation Number 14/17/PBI/2012 Article 17 paragraph (1) letter c explicitly reflects the Bank's obligation as the proxy not to transfer customer assets to third parties including replacement trustees even though there is an authorization from the Settlor to approve. This rule appears rigid and makes it difficult for customers unless the customer carries out a standard mechanism according to the due process of law in revoking the power that has been received by the first trustee based on a notary deed and revocation of the trustee agreement.

If the loss in management activities arises as a result of the Bank failing to fulfill the obligation to provide the risk management system as described above, then the Bank must be liable based on illegal acts, namely not fulfilling obligations under Article 31 PBI. In addition to negligence in fulfilling risk management, the Bank must bear losses due to failure to fulfill the obligations contained in the trustee agreement. Thus, the responsibility of the Bank as trustee can arise due to negligence in fulfilling obligations under the legislation and trustee agreements. In this case, the Bank must be responsible for replacing the losses incurred by both the Settlor and beneficiary. In the event that Bank experiences insolvency, the funds that are still managed and invested must be withdrawn by the Bank with the assistance of the Financial Services Authority with the legal consequences of the insolvency. Regarding the existence of a legal mechanism to require capital markets to cancel and withdraw funds that have been invested in third parties are not easy matters depending on what type of investment the Bank does. However, if the agreement has been included in the clause concerning the transfer to the new trustee, the transfer of authority will take effect automatically when the Bank is declared bankrupt. The concept of remote bankruptcy in Trust, according to the common law system, is adopted by Bank Indonesia Regulation Number 14/17/PBI/2012. As such, trust wealth obtains legal certainty in settlement of safekeeping agreements with management. In case, if the Bank is liquidated or transferred to safekeeping by its management to a substitute trustee, then the trust property must be returned to the Settlor or transferred to the replacement trustee. The bank must be responsible if the loss arises due to the negligence of the Bank in the form of negligence in complying with the obligations arising from the laws and regulations as well as from the Trustee agreement. Thus, the Bank can be held accountable for losses based either on illegal acts or defaults based on agreements and related laws and regulations in a casual manner. 
Particularly in the case of banking lending, there is a mandatory provision that must be made on the return of settlor assets either by the Bank or with the help of a curator, as implemented in Article 46 of Bank Indonesia Regulation Number 14/17/PBI/2012. The returned assets must be in accordance with the agreement so that from the beginning of the trustee agreement, the Bank has prepared a protective shield to repay the trust assets by using the guarantee mechanism of the Deposit Insurance Corporation even though in practice the Bank should not use the trust assets beyond the terms of the agreement. Referring to Government Regulation Number 25 of 1999 concerning Bank Insolvency, Insolvency Teams and Banking Organ must coordinate in preparing data and information on assets, bank rights and obligations that have not been completed up to the 5 year period from the date of the insolvency team establishment to the asset auction mechanism banking if the insolvency process takes more than 5 (five) years. This Government Regulation was later replaced by the provisions of the Deposit Insurance Corporation Act, which cut the insolvency of 5 (Five) Years into 2 (Two) Years with an extension of 2 (Two) times - each at the longest 1 (One ) Year. What if the return of the settlor property in the agreement is made before the insolvency takes place? According to the concept of separation of trust property and banking, it can be done as long as there is a notification to the insolvency team regarding the validity of the property rights of the assets or assets not mixed with the assets of the Bank. Such verification is based on a trustee agreement and attachment of evidence documents and administration for the ownership of trust assets on behalf of customers or settlors. As to prevent fraud and misuse of trust property and banking assets in the insolvency process, the government requires the deactivation of status and legal actions of directors and or commissioners until the insolvency process is completed.

It is well known that the legal relationship that occurs in a trustee agreement is a contractual agreement that binds the parties to the agreement. However, in this case, the government can take legal actions to protect the interests of the customers in the trustee agreement considering that banking activities have become a broader public need so government intervention is needed to determine policies or regulations relating Trustee agreement so that the interests of legal subjects within the Trust can be protected. The government could be taking part in the making of regulations as a legal umbrella in terms of bank business activities in the Trustee agreement. In addition to using the mechanism for making legislation, the government also actively acts through the hands of the Financial Services Authority in managing assets through investments in the Capital Market. Nevertheless, in this case, the supervision that can be carried out by the Financial Services Authority can be ineffective with the many oversight responsibilities given to the Financial Services Authority. So that in this case, there is a need for delegation of authority and proper coordination between the capital market authorities, banks, especially active reporting on the development of such trust services in detailed monthly or annual reports. In contrast to the capital market mechanism that protects with the prospectus and trustee in bonds, in this 
case, there is a need for regulation regarding the authorities to carry out internal and external oversight of the interests of customers, especially to check whether the Bank has taken legal action caution.

\section{Conclusion}

It would be legal consequences in the trustee agreement, such as each party giving the rights and obligations in written form. The main consequence of the bank become a trustee is the bank has to maintain the settlor's asset safely and manage the asset based on the agreement; meanwhile, the settlor is needed to give the transparency of the asset to avoid any criminal conduct. Furthermore, the conclusion of legal issues is the inclusion of customer assets in the trustee agreement as bankrupt assets are a violation of the agreement and violation of the law so that the action is to use the mechanism of civil law based on the principle of Liability.

On the other hand, the parties have to understand this trustee agreement carefully, especially regarding the possibility of management failures and operational failures made with the bank. Banks and customers can request assistance from independent third parties as supervisors and reporters to customers regarding the bank's performance in managing the assets.

\section{References}

Abubakar, L., \& Handayani, T. (2017). Perkembangan transaksi perbankan dan implikasinya terhadap pembaruan hukum perdata indonesia. Justicia Jurnal Hukum, 1(2), 241-266. http://dx.doi.org/10.30651/justitia.v1i2.1149

Angellie Siregar, M. G. J. (2016). Eksekusi jaminan dalam kepailitan pada kreditor separatis ketika ditangani oleh Kurator. Jurist-Diction Law Journal, 1(2), 599608. Retrieved from https://e-journal.unair.ac.id/JD/article/view/11011/6237

Budhijana, B., \& Nelmida. (2018). Analisis risiko kebangrutan pada perusahaan bank umum swasta nasional yang terdaftar di Bursa Efek Indonesia. Jurnal Akuntansi Keuangan Dan Bisnis, 11(1), 99-109. Retrieved from https://jurnal.pcr.ac.id/index.php/jakb/article/view/1618

Concessional Finance and Global Patnership. (2009). Trust fund at the World Bank : A guide for donors and partners. Concessional Finance and Global Patnership.

Cranton, R., \& All, E. (2017). Principle of banking law. Oxford University Press.

Fuady, M. (2017). Hukum bisnis dalam teori dan praktek (3rd ed.). Yogyakarta: Aditya Bakti.

Ginting, R., Murniadi, C., Astiyah, S., Iskandar, D., Sitompul, Z., Wuryandani, G., ... Primadhyta, S. (2013). Kodifikasi peraturan Bank Indonesia. Retrieved from https://www.bi.go.id/id/peraturan/kodifikasi/bank/Pages/1.3.5.2. Kegiatan Usaha Bank Berupa Penitipan dengan Pengelolaan (Trust).aspx

Hartana, A. (2016). Hukum Perjanjian: Dalam perspektif perjanjian karya Pengusahaan Pertambangan Batubara. Jurnal Komunikasi Hukum, 2(2), 147281. http://dx.doi.org/10.23887/jkh.v2i2.8411

Hatrik, H. (2012). Pertanggungjawaban pidana korporasi sebagai subjek hukum artifisial. Unpublished Thesis. Universitas Brawijaya.

Hesti, S. (2016). Pertanggungjawaban pidana kurator berdasarkan prinsip independensi menurut hukum kepailitan. Yuridika, 31(3), 440-473. 


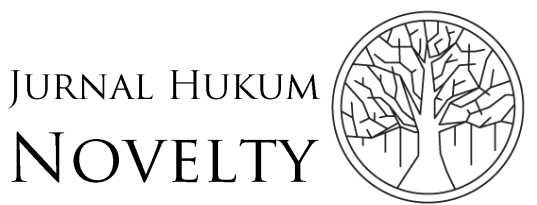

Volume 10, Issue 02, 2019, pp. 111-129

http://dx.doi.org/10.20473/ydk.v31i3.4794

Hukum Online. (2013). Sembilan bank siap jadi trustee. Retrieved February 2, 2019, from Hukum Online website: https://www.hukumonline.com/berita/baca/lt515ecca5e2652/sembilanbank-siap-jadi-trustee/

Johanes, R. (2016). Kajian hukum terhadap likuidasi dan kepailitan bank berdasarkan Undang-Undang Nomor 10 Tahun 1998 tentang Perbankan. Lex et Societatis, 4(4), 54-62. $\quad$ Retrieved from https://ejournal.unsrat.ac.id/index.php/lexetsocietatis/article/view/11895/1 1484

Krismen, Y. (2014). Pertanggungjawaban korporasi dalam kejahatan ekonomi. Jurnal Ilmu Hukum, 4(1), 133-160. Retrieved from https://ejournal.unri.ac.id/index.php/JIH/article/view/2089

Lubis, M. F. R. (2018). Pertanggungjawaban direksi di suatu Perseroan Terbatas ketika terjadi kepailitan pada umumnya dan menurut doktrin hukum perusahaan \& Undang- Undang No. 40 Tahun 2007. Jurnal Hukum Kaidah: Media Komunikasi dan Informasi Hukum dan Masyarakat, 17(2), 25-47. Retrieved from https://jurnal.uisu.ac.id/index.php/jhk/article/view/350

Mertokusumo, S. (2010). Mengenal hukum. Yogyakarta: Cahaya Atma Pustaka.

Nieuwenhuis, J. (n.d.). Hoofdstuken verbintenissenrecht (D. S. (Translator), Ed.). Surabaya.

Onakoya, A. B., \& Olotu, A. E. (2017). Bankruptcy and insolvency: An exploration of relevant theories. International Journal of Economics and Financial Issues, 7(3), 706-712. Retrieved

from https://dergipark.org.tr/en/pub/ijefi/issue/32021/354317

Ramadhani, A. S., \& Lukviarman, N. (2009). Perbandingan analisis prediksi kebangkrutan menggunakan model altman pertama, altman revisi, dan altman modifikasi dengan ukuran dan umur perusahaan sebagai variabel penjelas. Jurnal Siasat Bisnis, 13(1), 15-28. Retrieved from https://journal.uii.ac.id/JSB/article/view/2011

Setiawan, M. R. (2017). Implementasi prinsip mengenal nasabah sebagai upaya pencegahan tindak pidana pencucian uang. Jurnal Diversi, 3(2), 139-156. https://doi.org/10.32503/diversi.v3i2.160

Saito, K., Hiyama, K., \& Shiotani, K. (2018). International comparison of the BIS international banking statistic: Estimates of the positions excluding trustee business. Bank of Japan Review, E(2), 1-6. Retrieved from https://ideas.repec.org/p/boj/bojrev/rev18e02.html

Syamlan, Y. T. (2017). Does dual banking system in Indonesia differentiate investment account requirement? Tazkia Islamic Finance and Business Review, 11(1), 81106. Retrieved from http://www.tifbrtazkia.org/index.php/TIFBR/article/view/132

The World Bank. (2015). Operational manual bank procedures. The World Bank.

Usman, R. (2016). Kepailitan terhadap bank berdasarkan asas keseimbangan sebagai perwujudan perlindungan kepentingan nasabah penyimpan. Badamai Law Journal, 1(1), 141-158. Retrieved from https://studylibid.com/doc/1005088/kepailitan-terhadap-bank-berdasarkanasas-keseimbangan-se...

Wafa, M. A. (2017). Hukum perbankan dalam sistem operasional bank Konvensional dan bank syariah. Kordinat, 16(95), 257-270. Retrieved from 
http://journal.uinjkt.ac.id/index.php/kordinat/article/view/6441

Wafiya. (2012). Perlindungan hukum bagi nasabah yang mengalami kerugian dalam transaksi perbankan melalui internet. Kanun Jurnal Ilmu Hukum, 14(1), 353-365. Retrieved from http://www.jurnal.unsyiah.ac.id/kanun/article/view/5929

Wahanu, P. H. (2015). Trust fund: Hukum internasional dan penerapannya. Majalah Compact, Desember(10), 27-29. Retrieved from http://birohukum.bappenas.go.id/data/data_artikel_jdih/Majalah\%20Compac t\%20Dec\%202015.pdf

Wiwoho, J. (2014). Peran Lembaga Keuangan Bank Dan Lembaga Keuangan Bukan Bank Dalam Memberikan Distribusi Keadilan Bagi Masyarakat. MasalahMasalah Hukum, 43(1), 87-97. Retrieved from https://ejournal.undip.ac.id/index.php/mmh/article/view/9028/7333

Yudh, W. A. (2017). Perbuatan melanggar hukum sebagai sumber utang dalam Undang-Undang Nomor 37 Tahun 2004 tentang kepailitan dan penundaan kewajiban pembayaran utang. Rechtidee, 12(2), 209-222 Retrieved from https://journal.trunojoyo.ac.id/rechtidee/article/view/3339 